\section{Proteinuria: Assessment and Utility in Lupus Nephritis}

\author{
Jorge Medina-Rosas and Zahi Touma* \\ Centre for Prognosis Studies in the Rheumatic Diseases, Toronto Western \\ Hospital, University of Toronto Lupus Clinic, Toronto, Ontario, Canada
}

\begin{abstract}
Lupus has an incidence of kidney involvement of $54 \%$. The most common manifestation of lupus nephritis is proteinuria. Proteinuria is a biological marker of disease activity and renal damage and it is included in lupus disease activity and damage indices. Proteinuria produces fibrosis of the renal tubules and interstitium, leading to chronic kidney disease. There is a known association between proteinuria and vascular inflammation, increasing the risk for cardiovascular disease. Clinicians managing lupus can use the Protein-creatinine Ratio (PCR) in a spot urine sample to screen for proteinuria. Although different cut-offs of PCR in order to predict proteinuria levels have been suggested, the gold standard test to accurately quantify proteinuria in lupus is based on the protein content in a 24-hour urine collection.
\end{abstract}

Keywords: Kidney; Lupus nephritis; Systemic lupus erythematosus

\section{Introduction}

Systemic Lupus Erythematosus (SLE) is a chronic autoimmune disease with a cumulative incidence of kidney involvement of 54\% [1]. Lupus Nephritis (LN) has a higher incidence in some ethnic groups such as African Americans (35 to 51\%), Hispanics (31 to 43\%), and Asians (33 to 55\%) as compared to Caucasians (14 to 23\%) [1,2]. Proteinuria is the most common manifestation of $\mathrm{LN}$, being reported in almost $100 \%$ of patients, followed by granular casts, cellular casts, hematuria and reduced renal function [3]. Proteinuria is one of the best available biomarker for assessing kidney involvement in SLE [4] and for monitoring response to therapy and progression of the disease [5]. Because of the importance of proteinuria in SLE and LN, it is necessary to understand its role for the diagnosis of $\mathrm{LN}$, for the determination of lupus disease activity and for prognosis. In addition, identifying the appropriate screening and quantitative tests for proteinuria is crucial (Figure 1).

*Corresponding author: Zahi Touma, Centre for Prognosis Studies in the Rheumatic Diseases, Toronto Western Hospital, University of Toronto Lupus Clinic, EW, 1-412, 399 Bathurst Street, Toronto, Ontario M5T 2S8, Canada, Tel: +1 4166035248; Fax: +1 4166039387; E-mail: zahi.touma@uhn.ca

Citation: Medina-Rosas J, Touma Z (2016) Proteinuria: Assessment and Utility in lupus Nephritis. J Orthop Res Physiother 2: 027.

Received: October 20, 2015; Accepted: December 30, 2015; Published: January 10, 2016

Copyright: (C) 2016 Medina-Rosas J and Touma Z, This is an open-access article distributed under the terms of the Creative Commons Attribution License, which permits unrestricted use, distribution, and reproduction in any medium, provided the original author and source are credited.

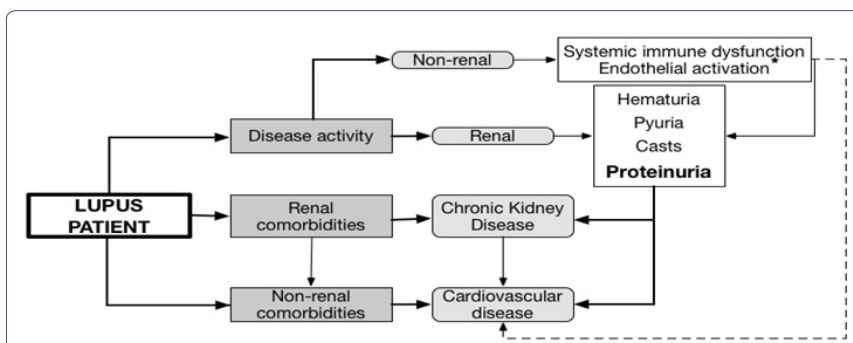

Figure 1: Importance of proteinuria in the management of patients with lupus. Hematuria: $>5$ red blood cells/high power field. Exclude stone, infections or other causes

Pyuria: $>5$ white blood cells/high power field. Exclude infection

Cellular casts: Heme-granular or red blood cell casts

*Systemic endothelial activation predisposes to cardiovascular disease

\section{Methods for Assessment of Proteinuria}

Proteinuria is defined as an abnormal excretion of protein in urine. The amount of protein in a 24 -hour urine collection (24H-P) from a healthy adult should not be more than $150 \mathrm{mg} /$ day (equivalent to a Protein to Creatinine Ratio [PCR] of an untimed spot urine sample of $15 \mathrm{mg} / \mathrm{mmol}$ ) [6,7]. Proteinuria is a cardinal biomarker in renal disease and there are 4 accepted methods for its assessment: 2 semiquantitative (urine dipstick and Sulfosalicylic Acid test [SSA]) and 2 quantitative (PCR and $24 \mathrm{H}-\mathrm{P}$ ).

\section{Urine dipstick}

It is most commonly used as a screening method for proteinuria because of its convenience for the patients and provides a rapid assessment. This method detects albuminuria with a lower limit of approximately 10 to $20 \mathrm{mg} / \mathrm{dL}$. However, it's subjective and has low sensitivity for proteins different than albumin and it has many false positive results in the following conditions: low urine volume, concentrated urine and urinary tract infection. In dilute urine samples, the dipstick might be falsely negative. Thus, the urine dipstick is an unsuitable confirmatory test and the dipsticks that provides quantitation of albuminuria (e.g., trace, $1+, 2+$ and $3+$ ) are not reliable as well [8].

\section{SSA}

It detects all kind of urine proteins including non-albumin proteins (e.g., immunoglobulin light chains) with a lower limit of detection of 5 to $10 \mathrm{mg} / \mathrm{dL}$. SSA is mainly used for the detection of myeloma kidney. The SSA has false positive results when an iodinated contrast agent is used [9] and an abnormal SSA result should be confirmed with a quantitative test.

\section{H-P}

This is the gold standard method for quantifying proteinuria. $24 \mathrm{H}-\mathrm{P}$ has many advantages over other methods and it is not affected by the variations in protein excretion throughout the day and external factors such as exercise and diet [10]. However, this test also has disadvantages: It is cumbersome for patients, it is time-consuming and it is prone to errors if the patient does not follow the instructions correctly [8]. 


\section{PCR}

Proposed by Ginsberg et al., to assess nephrotic range proteinuria and to circumvent the problems with the 24-hour urine collection. Originally PCR was developed for the assessment of ambulatory patients followed at renal clinics. PCR is based on the assumption that the protein and the creatinine excretions are stable during the full day and that PCR would reflect the cumulative protein excretion during a 24-hour period. However, in many situations this is not the case and there is a variation in the excretion of protein during the day jeopardizing the validity of PCR $[11,12]$.

\section{Proteinuria in Lupus as a Marker of Kidney Involvement}

The gold standard test for the diagnosis of LN is kidney biopsy [13]. An abnormal value of proteinuria in SLE has been recognized as a biological marker for kidney disease, with or without the presence of significant urine red blood cells (hematuria: $>5$ red blood cells/high power field), white blood cells (pyuria: $>5$ white blood cells/high power field) or cellular casts (heme-granular or red blood cell casts) [14-16]. In clinical practice abnormal new proteinuria as yet undiagnosed proteinuria is often the trigger for kidney biopsy in lupus. The clinical significance of other urine abnormalities, such as isolated hematuria or pyuria, is not clearly defined. Ding et al., suggested that isolated hematuria or pyuria could be related to renal and non-renal disease activity one year prior and one year after its finding, thus it could be attributed to a phase of active disease [17] For the group of patients with silent LN (abnormal kidney histology and absence of proteinuria or active urinary sediments), there is a lack of supporting evidence on treatment and followup. Therefore, it is unclear whether these patients will progress to develop CKD [18]. In SLE, clinically significant proteinuria is defined as a $24 \mathrm{H}-\mathrm{P}$ higher than $0.5 \mathrm{~g} /$ day. This cut-off of proteinuria has been accepted as one of the features for the case definition in the American College of Rheumatology (ACR) guidelines [19], the European League Against Rheumatism and European Renal Association-European Dialysis and the Transplant Association recommendations for the for screening, treatment and diagnosis of LN [20]. Even though some authors suggest using the PCR, Houssiau et al., highlighted the importance of a $24 \mathrm{H}-\mathrm{P}$ for proteinuria measurement as part of a complete initial evaluation of the patient with SLE and possible LN [21]. Moreover, Corapi et al., emphasized that PCR may lack accuracy for the quantification of proteinuria in LN compared to other glomerulopathies [22], thus the evidence favors $24 \mathrm{H}-\mathrm{P}$.

\section{Proteinuria in Lupus as a Marker of Disease Activity}

The pathophysiology of the LN includes systemic and renal cellular and humoral responses that impair the function of the Glomerular Filtration Barrier (GFB), allowing abnormal sized proteins to be excreted in urine, in higher than normal amounts [23]. The deposit of auto-antibodies in glomeruli results in tubular damage, tubule-interstitial inflammation and fibrosis [24]. Once the immune activity from lupus is controlled, in the absence of CKD, proteinuria should normalize. A recurrence of proteinuria is associated with a lupus nephritis flare [25]. Proteinuria is the main manifestation of all the subtypes of histological LN [26,27], and nephrotic range proteinuria ( $>3.5 \mathrm{~g} /$ day) is associated with the classes III, IV and $\mathrm{V}$ from the International Society of Nephrology/Renal Pathology Society (ISN/RPS) classification system $[3,28]$.

Proteinuria is routinely assessed in clinical practice and abnormal results develop earlier than the deterioration in estimated Glomerular
Filtration Rate (GFR), making it more suitable for evaluating kidney function and activity in SLE [22]. Proteinuria has a better diagnostic accuracy than other classical biomarkers such as the urinary sediments (pyuria, hematuria and casts). For instance, the presence of active urine sediments is a strong surrogate of ongoing kidney inflammation, but the reliability of a urine sediment test and its interpretation are operator-dependent. Although proteinuria is considered a very important biomarker in the assessment of LN activity, the renal biopsy remains the 'gold' standard for the diagnosis of LN and its severity. However, the renal biopsy is considered an invasive test and the proteinuria has some caveats, thus there is an unmet need to find the best marker of LN activity and a marker to predict LN. Some of the caveats that preclude proteinuria from being considered the "gold standard" test are listed here: 1) Inability to differentiate between disease activity and damage; for instance, low grade or persistent proteinuria may be a manifestation of ongoing LN activity or a result of kidney scars; 2) total proteinuria doesn't differentiate urine albumin from high molecular weight proteins (as in severe Glomerular lesions thus proteinuria can't differentiate between Glomerular and tubular protein [29]; and 3) the attribution of proteinuria to LN activity might be very challenging in patients with SLE and other kidney disease (e.g., diabetes, hypertensive nephropathy and other).

Several studies have evaluated the role of novel prognostic and diagnostic biomarkers in the assessment of LN. Few novel biomarkers of LN activity provide similar evidence compared to proteinuria. For instance, it was found that the urinary monocyte chemoattractanct protein-1 correlates with proteinuria level [30]. However, this biomarker has a cost burden and doesn't provide additional clinical value over proteinuria. Brunner et al., recently developed and validated the Renal Activity Index for Lupus [RAIL] against the degree of histological activity of kidney biopsy in children with active LN. This novel index encompasses several urinary biomarkers (urinary Neutrophil Gelatinase Associated Lipocalin [NGAL], Monocyte Chemotactic Protein 1 [MCP-1], ceruloplasmin, adiponectin, hemopexin, and Kidney Injury Molecule 1 [KIM-1]) [31]. Although these biomarkers seem very promising, further studies are needed to validate its use in $\mathrm{LN}$ and determine its added prognostic and diagnostic value to the existing marker "proteinuria".

The renal system is included in the majority of lupus disease activity indices (e.g., Systemic Lupus Erythematosus Disease Activity Index-2000 [SLEDAI-2K] where the renal system encompasses 4 descriptors: proteinuria, hematuria, casts and pyuria) $[15,16]$ and in each one of these indices, proteinuria has a pivotal role in the assessment of kidney disease [32]. The original SLEDAI [33] was modified in its new version, SLEDAI-2K, to measure and score persistent proteinuria as opposed to only new and recurrent proteinuria [15]. This change in SLEDAI-2K highlights the importance of recognizing proteinuria $(>0.5 \mathrm{~g} /$ day) (new, recurrent or persistent) as evidence of disease activity [15]. The British Isles Lupus Assessment Group index 2004 (BILAG-2004) includes the renal system with clinical descriptors (systolic and diastolic blood pressure, presence of accelerated hypertension, presence of nephrotic syndrome, and presence of active nephritis) and laboratory descriptors (urine dipstick protein, urine albumin/creatinine ratio, PCR, 24H-P, creatinine, calculated Glomerular filtration rate, and active urinary sediment) [34]. Although ACR guidelines define $24 \mathrm{H}-\mathrm{P}>0.5 \mathrm{~g} /$ day as a case definition for LN [19], there is a lack of homogeneity in the amount of proteinuria to be considered "active 
disease" in the lupus disease activity instruments. For instance, the proteinuria level necessary in total and partial renal recovery differs among recent trials on LN [35-37], making it difficult to compare outcomes/endpoints $[38,39]$. Moreover, the proposed ACR threshold for proteinuria $(0.5 \mathrm{~g} /$ day) required reflecting clinically significant $\mathrm{LN}$ differs in lupus disease activity indices [19]. For instance, SLEDAI-2K [15] and European Consensus Lupus Activity Measurement index (ECLAM) [40] include proteinuria as a renal disease activity marker with a $24 \mathrm{H}-\mathrm{P}>0.5 \mathrm{~g} /$ day. In BILAG-2004, the proteinuria is graded differently based on its amount (A [active disease] $=>1.0 \mathrm{~g} /$ day; $\mathrm{B}$ $[$ beware $]=>0.5 \mathrm{~g} /$ day, $\mathrm{C}$ [contentment $]=>0.25 \mathrm{~g} /$ day) and it can be obtained from a $24 \mathrm{H}-\mathrm{P}$ or a PCR [41]. The SLE Activity Index Score (SIS) divides proteinuria based on the cut off of $1.5 \mathrm{~g} / \mathrm{d}$ and gives 1 or 2 points respectively for the final score as follows: 1 point for $24 \mathrm{H}-\mathrm{P}$ $<1.5 \mathrm{~g} /$ day and 2 points for $24 \mathrm{H}-\mathrm{P}>1.5 \mathrm{~g} /$ day [42]. The SLE Activity Measure-revised (SLAM-R) does not include proteinuria among the renal descriptors [40].

\section{Proteinuria in Lupus as a Prognostic Factor for Renal Outcomes}

Proteinuria in lupus has a pivotal prognostic value on renal outcomes: Remission of $\mathrm{LN}$, progression to $\mathrm{CKD}$, renal replacement therapy or kidney transplantation. Proteinuria is a risk factor for progression of $\mathrm{CKD}$, in part because of its proinflammatory and profibrotic effect on kidneys [43].

High proteinuria (nephrotic syndrome) is associated with multi-systemic vascular damage leading to worsening GFR [44]. Proteinuria induces structural and functional changes in different kidney cells; with more protein traffic to the proximal/distal collecting ducts and subsequent inflammation and fibrosis, and progressive loss of kidney function [45]. Proteinuria produces active glomerular inflammation and can be considered a manifestation of an Acute Kidney Injury (AKI), which is a recognized risk factor for CKD [46]. Touma et al., demonstrated that proteinuria is a marker for the long term prognosis of kidney function [47]. Nevertheless, there is no agreement on the thresholds of proteinuria to achieve Complete Remission (CR) or Partial Remission (PR), in order to prevent or to slow the decline in kidney function [48] (Table 1). Wofsy et al., suggested that some kidney abnormalities can be irreversible, and therefore it is not always possible to achieve a CR of proteinuria. Their proposed Major Clinical Response (MCR), where combining the percentages of patients achieving $\mathrm{CR}$ and $\mathrm{PR}$ of proteinuria, would improve the end points in trials at $1^{\text {st }}$ year. Notwithstanding, it is still important to determine the prognostic value of MCR on long-term kidney outcomes [51].

In SLE the cut-off of $0.5 \mathrm{~g} /$ day has been accepted by the ACR as the target to achieve and reflects CP recovery [19], and this cut-off has been used in studies comparing treatments for induction or maintenance of immunosuppressive therapy [50]. Nonetheless, other authors have used different cut offs for PR and CR of proteinuria. Koo et al., defined remission (CR) as a PCR $<0.3 \mathrm{~g} / \mathrm{g}$; Chan et al., used $24 \mathrm{H}-\mathrm{P} 0.3 \mathrm{~g} /$ day as the criteria for remission [52]. Wofsy et al., highlighted on the non homogeneity of outcomes which could explain different conclusions of recent studies [38]. Dall'Era et al., analyzed patients from the Euro-Lupus Nephritis trial and determined that the $24 \mathrm{H}-\mathrm{P}$ at 12 months was the best predictor of creatinine $\leq 1 \mathrm{mg} / \mathrm{dl}$ at 7 years of follow up, with a better sensitivity and specificity for $24 \mathrm{H}-\mathrm{P}$ of $0.8 \mathrm{~g} /$ day $(0.81$ and 0.78 , respectively) compared to $0.5 \mathrm{~g} /$ day ( 0.64 and 0.83 respectively) [53]. The analyses

\begin{tabular}{|c|c|c|c|c|}
\hline Authors & Year & $\begin{array}{c}\text { Definition of } \\
\text { proteinuria }\end{array}$ & Definition of CR & Definition of PR \\
\hline $\begin{array}{c}\text { ACR criteria* } \\
\text { [49] }\end{array}$ & 2006 & & $\begin{array}{l}\geq 50 \% \text { reduction } \\
\text { in } \mathrm{PCR} \text { and } \mathrm{PCR} \\
\quad<0.2 \mathrm{~g} / \mathrm{g}\end{array}$ & $\begin{array}{c}\geq 50 \% \text { reduction } \\
\text { in } P C R \text { and } P C R \\
0.2-2.0 \mathrm{~g} / \mathrm{g}\end{array}$ \\
\hline Hahn [19] & 2012 & PCR $>0.5 \mathrm{~g} / \mathrm{g}$ & & \\
\hline Bertsias [20] & 2012 & $\begin{array}{c}24 \mathrm{H}-\mathrm{P}>0.5 \\
\text { g/day }\end{array}$ & & \\
\hline $\begin{array}{c}\text { The ACCESS } \\
\text { trial group } \\
\text { [35] }\end{array}$ & 2014 & $\mathrm{PCR}>1.0 \mathrm{~g} / \mathrm{g}$ & $\mathrm{PCR}^{1}<0.5 \mathrm{~g} / \mathrm{g}$ & $\begin{array}{l}\text { Reduction of } \\
\mathrm{PCR}^{1} \geq 50 \% \text { of } \\
\text { baseline level }\end{array}$ \\
\hline $\begin{array}{c}\text { Appel } \\
\text { [ALMS] [36] }\end{array}$ & 2009 & $\begin{array}{c}24 \mathrm{H}-\mathrm{P} \geq 2.0 \mathrm{~g} / \\
\text { day } \mathrm{LN} \text { classes } \\
\text { III or } V\end{array}$ & \multicolumn{2}{|c|}{$\begin{array}{c}\text { Responders } \\
\mathrm{PCR}^{1}<3.0 \text { (if baseline } \mathrm{PCR} \geq 3.0 \text { ) } \\
\text { Reduction of } \mathrm{PCR}^{1} \geq 50 \% \text { of baseline } \\
\text { (if baseline } \mathrm{PCR}<3.0 \text { ) }\end{array}$} \\
\hline $\begin{array}{c}\text { Rovin } \\
\text { [LUNAR] [37] }\end{array}$ & 2012 & $\mathrm{PCR}>1.0 \mathrm{~g} / \mathrm{g}$ & $\mathrm{PCR}<0.5 \mathrm{~g} / \mathrm{g}$ & $\begin{array}{c}\mathrm{PCR}<1.0 \mathrm{~g} / \mathrm{g} \text { (if } \\
\text { baseline } \mathrm{PCR} \leq \\
3.0 \mathrm{~g} / \mathrm{g} \text { ) } \\
\mathrm{PCR} \leq 3.0 \mathrm{~g} / \mathrm{g} \text { (if } \\
\text { baseline } \mathrm{PCR}> \\
3.0 \mathrm{~g} / \mathrm{g} \text { ) }\end{array}$ \\
\hline $\begin{array}{c}\text { Houssiau } \\
\text { [MAINTAIN } \\
\text { nephritis trial] } \\
{[50]}\end{array}$ & 2010 & $\begin{array}{c}24 \mathrm{H}-\mathrm{P}>0.5 \\
\text { g/day }\end{array}$ & \multicolumn{2}{|c|}{$\begin{array}{c}\text { Renal remission } 24 \mathrm{H}-\mathrm{P}<1.0 \mathrm{~g} \text { ] } \\
\text { Flare: serum albumin } \leq 3.5 \mathrm{~g} / \mathrm{dl} \text { and } \\
24 \mathrm{~h} \text { proteinuria } \geq 3 \mathrm{~g}\end{array}$} \\
\hline
\end{tabular}

Table 1: Comparison of the definitions of proteinuria in the diagnosis of lupus nephritis and in the endpoints of complete and partial remission of lupus nephritis.

*ACR response criteria for Proliferative and Membranous Renal Disease in SLE Clinical Trials

CR: Complete Remission; SLE: Systemic Lupus Erythematosus; PCR: Spot urine Protein/Creatinine ratio; PR: Partial Remission; LN: Lupus Nephritis; $24 \mathrm{H}-\mathrm{P}$ : Proteinuria in a 24 hours urine collection

1. The PCR was calculated from a 24 hour-urine collection sample

2. In this study, the primary outcome was time to renal flare

of the Aspreva Lupus Management Study (ALMS) for factors associated with long-term renal outcomes showed that then on-reduction of PCR $\geq 25 \%$ within 8 weeks during induction was associated with treatment failure. For the patients who entered the maintenance phase, the CR was higher for those who entered this phase with PCR $\leq 1.0 \mathrm{~g} / \mathrm{g}$ vs those with PCR $\geq 1.0 \mathrm{~g} / \mathrm{g}(68 \%$ vs $43 \%$ respectively) [54].

Inflammatory diseases, as SLE, are linked directly (promoting chronic changes and tubulointerstitial fibrosis) and indirectly (promoting CVD) to CKD [55,56]. In SLE, nephritic and proteinuric flares (with increase in $24 \mathrm{H}-\mathrm{P}>1.0 \mathrm{~g}$ /day) of LN contribute equally to poor kidney outcomes [46], with heavy proteinuria resulting in a higher risk for CKD and end stage CKD with requirement for dialysis [57]. Fiehn et al., compared the renal prognosis of patients with LN in 2 groups: from 1980-1989 (group 1) and 1990-2000 (group 2), showing less histological signs of chronicity and proteinuria for group 2. The authors suggested that early diagnosis (clinical and histological [kidney biopsy]) and appropriate treatment improve kidney outcomes over time [58]. The addition of as $\mathrm{Cr} \leq 1.0 \mathrm{mg} / \mathrm{dl}$ to the $24 \mathrm{H}-\mathrm{P}<0.8 \mathrm{~g} /$ day target increased the specificity ( $87 \%)$ but lowered the sensitivity $(78 \%)$ for the prediction of good renal prognosis at 12 months, suggesting that the degree of proteinuria is of utmost importance for the development of CKD. Reich et al., showed that the time-averaged proteinuria was the predictor of the rate of progression of renal function decline [59], with higher decline for higher proteinuria: subjects with $24 \mathrm{H}-\mathrm{P} 0-1 \mathrm{~g} /$ day losing $1.15 \pm 5.37 \mathrm{ml} / \mathrm{min}$ per $1.73 \mathrm{mt}^{2}$ per year of GFR vs subjects with $24 \mathrm{H}-\mathrm{P}>2.0 \mathrm{~g} /$ day losing $6.68 \pm 14.6 \mathrm{ml} / \mathrm{min}$ per $1.73 \mathrm{mt}^{2}$ per year of GFR. The authors 
highlighted the importance of persistent proteinuria and indicated that in the short term, proteinuria is a predictor of doubling creatinine and developing CKD. Recently, Touma et al., showed that the development of long-term renal outcomes (e.g. CKD, dialysis or transplant) in patients who achieve CR (defined as $24 \mathrm{H}-\mathrm{P}<0.5 \mathrm{~g} /$ day) at 2 years are better than inpatients who only achieve PR (defined as decrease in $24 \mathrm{H}-\mathrm{P} \geq 50 \%$ from baseline but not $<0.5 \mathrm{~g} /$ day). The authors suggested that whenever it is possible, the clinician should aim for CR [47] (Figure 2). It is well accepted that proteinuria recovery (by recovery, we are referring to complete resolution of proteinuria to normal value as defined in disease activity indexes; for instance, in SLEDAI-K, normal proteinuria is defined as $24 \mathrm{H}-\mathrm{P}<0.5$ $\mathrm{g} /$ day [15]), is slow (with only $52 \%$ of patient achieving recovery at 2 years), and higher levels of proteinuria ( $\geq 2 \mathrm{~g} /$ day) at baseline visit of LN, male sex, hypocomplementemia, and lupus disease duration $>5$ years at onset of LN predict independently late recovery of proteinuria [5] (Figure 3). In summary, there is evidence from different cohorts that proteinuria is a risk factor for future development of CKD in SLE patients, and the clinician should address it during the follow-up of patients.

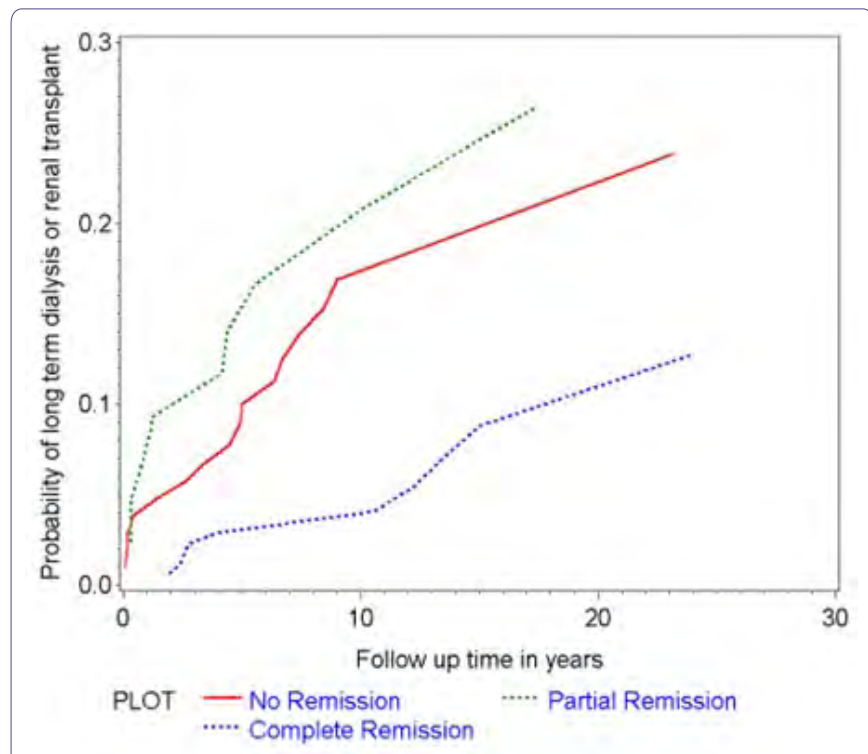

Figure 2: Long term outcomes: dialysis or renal transplant.

$\mathrm{P}$ Value comparing complete proteinuria remission and partial proteinuria remission: 0.015

$P$ value comparing partial proteinuria remission and no remission: 0.59

In this study, 326 patients with LN were studied. The results confirmed that achieving complete proteinuria remission at 2 years from diagnosis protects against the dialysis or renal transplant while partial proteinuria remission ( $\geq 50 \%$ but not to normal levels) or no recovery doesn't [47].

Proteinuria in Lupus as a Cardiovascular Prognostic Marker

Proteinuria is a marker of atherosclerosis and vascular disease in the general population [60] and in patients with diabetes mellitus [61], with an estimated $50 \%$ greater risk of Cardiac Heart Disease (CHD) than the healthy controls [62]. SLE patients in general have a higher risk of accelerated atherosclerosis than patients with Diabetes Mellitus (DM) [63].

Proteinuria in SLE can be secondary to active kidney disease or to chronic kidney damage [64]. During an active phase of the disease, there is a diffuse vascular damage secondary to endothelial

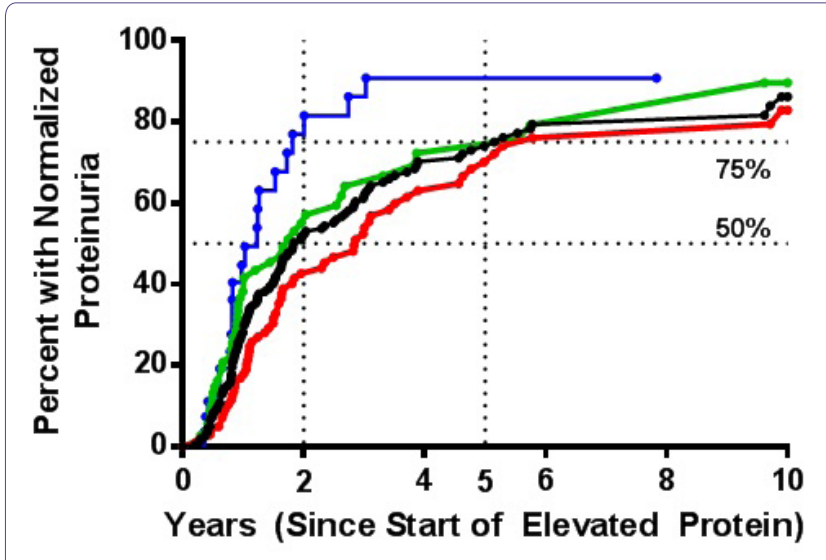

Proteinuria Group:

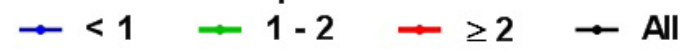

Figure 3: Kaplan-Meier curve for time to recovery from proteinuria in all patients and in 3 groups.

Proteinuria was defined as $\geq 0.5 \mathrm{~g} / 24$ hours. Patients were grouped into: group 1 having $0.5-0.9 \mathrm{~g} /$ day, group 2 having $1-1.9 \mathrm{~g} /$ day and group 3 having $\geq 2 \mathrm{~g} /$ day. Patients with a higher level of proteinuria at baseline needed a longer time to normalize their proteinuria.

(Published with permission for The Journal of Rheumatology; Touma Z et al. (2014) Time to recovery from proteinuria in patients with lupus nephritis receiving standard treatment. The Journal of rheumatology 41: 688-697)

dysfunction and apoptosis, been present in the kidney and in other systems as well [44], with the secondary development of abnormalities in the glomerular slit diaphragm and a pro-inflammatory vascular state that stimulates atherosclerosis [65]. Persistent proteinuria can accelerate the decline of the GFR and is a manifestation and a risk factor for Chronic Kidney Disease (CKD) [46].

Proteinuria and CKD are known risk factors for Cardiovascular Disease (CVD), as shown by different cohorts followed for more than 15 years [66]. Thus, proteinuria of active kidney disease or chronic kidney damage in SLE is associated with CVD and thus is considered a CVD prognostic factor. In SLE patients, there is an increased Mortality rate ( 9 fold greater) related to premature atherosclerosis, with a higher prevalence of obstructed coronary arteries compared to the healthy controls [67].

SLE patients, especially patients with LN have a higher prevalence of traditional CVD risk factors [68]. Nonetheless, these factors do not completely explain the excess of CVD mortality in this population [68] and proteinuria or other manifestations of LN could play an important role in this issue. Fernandez-Nebro et al., reported that SLE patients with renal involvement had a higher frequency of CVD events [69]. Falaschi et al., found an association between nephrotic range proteinuria and increased carotid intima-media wall thickness in juvenile onset lupus [70]. Similarly, Kammoun et al., found that nephrotic range proteinuria, hypertension and histological classes III and IV of the ISN/RPS classification system for $\mathrm{LN}$ as poor prognostic factors for patients overall and specifically for survival without renal replacement therapy [71]. In summary, these studies suggest that proteinuria in SLE is related to CVD morbidity and mortality and could explain the accelerated atherosclerosis in this population, with a worse prognosis for the patients with proliferative LN (Class III and IV) and nephrotic range proteinuria. 


\section{Measuring Proteinuria in the Follow up of Patients with Lupus}

Accurate quantification of proteinuria is essential since it hinges on the definitions of partial and complete remission of $\mathrm{LN}$ in research studies and clinical trials [39]. Partial and complete proteinuria remission is associated with a better prognosis and kidney survival than no remission, and CPR is better as an outcome [72].

The commonly accepted outcomes for proteinuria during the follow-up of patients with $\mathrm{LN}$ are $\mathrm{CR}$ or PR, but there is no homogeneity of definitions for these outcomes with different proteinuria cut offs (Table 1). Proteinuria regression is slow, as was shown by Touma et al., in the cohort of patients from the Toronto Lupus Clinic. The authors showed that $52 \%$ of patients who started with $24 \mathrm{H}-\mathrm{P}>0.5 \mathrm{~g} /$ day recovered within 2 years [5]. Whether this long lasting proteinuria is a manifestation of residual inflammation or of Glomerular adaptation to the chronic inflammatory/healing processes is still a matter of debate [73]. Studies have shown that lupus patients can develop LN late during the course of the disease (after 3 years from the diagnosis of SLE) [74], thus proteinuria must be accurately assessed at each visit.

In the follow up of SLE patients with proteinuria, the most precise test should be used to help the clinician to decide about response to treatment and the need for adjusting therapy. There are few articles comparing available tests for the follow-up of proteinuria in patients with glomerulonephritis. Antunes et al., followed a cohort of patients with primary non lupus related glomerulopathies for 6 months and determined that the PCR was an accurate test to define critical values of proteinuria (<0.2 g/day; $0.21-3.5 \mathrm{~g} /$ day; and $>3.5 \mathrm{~g} /$ day) [75].

Medina-Rosas et al., studied the change over time in proteinuria levels (improvement and worsening) using 2 methods for proteinuria measurement (24H-P vs PCR) in 1188-paired samples of 230 SLE patients [76]. In the group of patients at baseline with abnormal $24 \mathrm{H}-\mathrm{P}$ ( $>0.5 \mathrm{~g} /$ day), at 13.5 months all patients had a $50 \%$ improvement based on $24 \mathrm{H}-\mathrm{P}$ compared to $56 \%$ of patients based on PCR. At 17.5 months, all patients had complete proteinuria recovery ( $<0.5 \mathrm{~g}$ /day) based on $24 \mathrm{H}-\mathrm{P}$ compared to $53 \%$ of patients based on PCR. In the group of patients with proteinuria worsening over time based on $24 \mathrm{H}-\mathrm{P}$ (> $0.5 \mathrm{~g} /$ day) at 10.5 months, PCR captured only $79 \%$ of these patients. With the available evidence, it is prudent to use the PCR as a screening test and confirm any abnormal findings with a $24 \mathrm{H}-\mathrm{P}$.

\section{How to Accurately Measure Proteinuria in Lupus}

Proteinuria can result primarily of 2 types: Proteins that pass the GFB when a pathologic process affects this structure (e.g., inflammation, thrombosis or others) and proteins that are produced by the tubules (uromodulin) or the urinary tract [8]. In SLE, the abnormal amount of urine protein is due to the inflammatory process in the GFB that allows mainly albumin to pass the GFB and to appear in the urine. Three methods have been well accepted in the assessment of proteinuria in SLE: The dipstick, PCR, and the timed urine collection (the 24 hour urine collection, which is the most commonly used method).

The dipstick has been evaluated in patients with SLE in different studies and the results confirmed its low diagnostic accuracy. For instance, Chotayaporn et al., found a poor reliability between the dipstick and 24H-P [77]. Siedner et al., showed a high variability in the dipstick results and lack of validity of the dipstick to accurately quantify proteinuria levels compared to $24 \mathrm{H}-\mathrm{P}$ [78]. However, despite the disadvantages of dipstick, a recent survey among American rheumatologists showed that $65 \%$ are still using the dipstick method as the method for screening for proteinuria in SLE [79]. Based on a recent study by Medina-Rosas et al., it was concluded that PCR is a good screening test for proteinuria. In this study, a PCR level of $0.08 \mathrm{~g} / \mathrm{mmol}(800 \mathrm{mg} / \mathrm{g})$ was found to have a sensitivity of $91 \%$ and a specificity of $80 \%$, compared to a $24 \mathrm{H}-\mathrm{P}$ of $0.5 \mathrm{~g} / \mathrm{d}$ [80].

For clinicians treating SLE, the accurate determination of proteinuria is important for evaluating response to treatment or flares of LN [79]. The $24 \mathrm{H}-\mathrm{P}$ is the gold standard method for assessing and accurately determining the amount of proteinuria in SLE. Even though, the ACR recommends using the PCR every 1 to 6 months for monitoring LN depending on the patient disease activity and also recommend this approach for clinical trials [49], and The European League Against Rheumatism (EULAR) suggests the first morning PCR as a valid measure of proteinuria [20]. It is important to note that the level of proteinuria in diseases like DM or HTN nephropathies is not subject to frequent testing and it reflects damage as opposed to LN where it can occur in association with disease activity and damage.

Proteinuria occurring in the context of disease activity requires the use of an accurate test to quantify proteinuria levels periodically. Several studies in LN evaluated the validity of PCR compared to $24 \mathrm{H}-\mathrm{P}$ [81]. However, many of the studies used correlation as the primary statistical method for the comparison of PCR to $24 \mathrm{H}-\mathrm{P}$, the correlation is not the most appropriate method to be used in studies aiming to replace the gold standard test (e.g., 24H-P) [82]. The articles that used agreement methods showed poor diagnostic performance of the PCR compared to $24 \mathrm{H}-\mathrm{P}$, with less agreement for $24 \mathrm{H}-\mathrm{P}>1.0$ g/day $[80,83]$. Birmingham et al., showed poor agreement between PCR and 24H-P for SLE patients with proteinuria of 0.5 to $3.0 \mathrm{~g} /$ day [84]. Recently, these authors showed that the PCR is more unreliable in SLE than in other causes of CKD [85]. Medina-Rosas et al., studied 1,233 paired samples from 322 SLE patients and found a high correlation for all samples with lower correlation for subgroups of $24 \mathrm{H}-\mathrm{P}$, and poor agreement for all samples and subgroups, being worse for $24 \mathrm{H}-\mathrm{P}$ higher than $1.0 \mathrm{~g} /$ day [80]. Interestingly, this group found that the best cut-off of PCR that would predict a $24 \mathrm{H}-\mathrm{P}$ of 0.5 , 1 and $2 \mathrm{~g} /$ day should be $800 \mathrm{mg} / \mathrm{g}, 1600 \mathrm{mg} / \mathrm{g}$ and $3500 \mathrm{mg} / \mathrm{g}$, while Leung et al., found different values of cut-offs for 0.5 and $1 \mathrm{~g}$ /day (450 mg/g and $700 \mathrm{mg} / \mathrm{g}$ respectively) [86]. These findings confirm the validity of PCR as a screening test for proteinuria in LN, but there is still a lack of agreement on the best test to accurately quantify proteinuria (24H-P vs PCR). Recently, the evidence favoured $24 \mathrm{H}-\mathrm{P}$ over PCR because of the accuracy of the results [22,80,81]. A recent meta-analysis highlighted the methodological flaws of studies on the validity of PCR as a quantitative test for proteinuria and recommended the use of $24 \mathrm{H}-\mathrm{P}$ for accurate proteinuria measurement [81]. In addition, Corapi et al., also recommended the use of $24 \mathrm{H}-\mathrm{P}$ instead of PCR in clinical research and drug trials [22].

\section{Conclusion}

$\mathrm{LN}$ is very common in SLE patients with a cumulative incidence of $54 \%$ in SLE patients. Proteinuria is the most common finding of LN and it is important for the diagnosis of $\mathrm{LN}$, for the monitoring of $\mathrm{LN}$ activity and damage. The clinician's goal should be a CR of proteinuria $(24 \mathrm{H}-\mathrm{P}<0.5 \mathrm{~g} /$ day $)$, given the prognostic value of proteinuria on long term outcomes like CV and CKD. The PCR can be used as a screening test, but whenever there is an abnormal result, it should be confirmed by a $24 \mathrm{H}-\mathrm{P}$. 


\section{References}

1. Bastian HM, Roseman JM, McGwin G Jr, Alarcón GS, Friedman AW, et al. (2002) Systemic lupus erythematosus in three ethnic groups. XII. Risk factors for lupus nephritis after diagnosis. Lupus 11: 152-160.

2. Seligman VA, Lum RF, Olson JL, Li H, Criswell LA (2002) Demographic differences in the development of lupus nephritis: a retrospective analysis. Am J Med 112: 726-729.

3. Cameron JS (1999) Lupus nephritis. J Am Soc Nephrol 10: 413-424.

4. Balow JE (2005) Clinical presentation and monitoring of lupus nephritis. Lupus 14: $25-30$

5. Touma Z, Urowitz MB, Ibañez D, Gladman DD (2014) Time to recovery from proteinuria in patients with lupus nephritis receiving standard treatment. $J$ Rheumatol 41: 688-697.

6. Lamb EJ, MacKenzie F, Stevens PE (2009) How should proteinuria be detected and measured? Ann Clin Biochem 46: 205-217.

7. Methven S, MacGregor MS (2013) Empiricism or rationalism: how should we measure proteinuria? Ann Clin Biochem 50: 296-300

8. Viswanathan G, Upadhyay A (2011) Assessment of proteinuria. Adv Chronic Kidney Dis 18: 243-248.

9. Morcos SK1, el-Nahas AM, Brown P, Haylor J (1992) Effect of iodinated water soluble contrast media on urinary protein assays. BMJ 305: 29.

10. Buzio C, Mutti A, Capani F, Andrulli S, Perazzoli F, et al. (1989) Circadian rhythm of proteinuria: effects of an evening meat meal. Nephrol Dial Transplant 4: 266-270.

11. Fine DM, Ziegenbein M, Petri M, Han EC, McKinley AM, et al. (2009) A prospective study of protein excretion using short-interval timed urine collections in patients with lupus nephritis. Kidney Int 76: 1284-1288.

12. Naresh CN, Hayen A, Craig JC, Chadban SJ (2012) Day-to-day variability in spot urine protein-creatinine ratio measurements. Am J Kidney Dis 60: 561566.

13. Anders HJ, Fogo AB (2014) Immunopathology of lupus nephritis. Semin Immunopathol 36: 443-459.

14. Tan EM, Cohen AS, Fries JF, Masi AT, McShane DJ, et al. (1982) The 1982 revised criteria for the classification of systemic lupus erythematosus. Arthritis Rheum 25: 1271-1277.

15. Gladman DD, Ibañez D, Urowitz MB (2002) Systemic lupus erythematosus disease activity index 2000. J Rheumatol 29: 288-291.

16. Touma Z, Urowitz MB, Ibañez D, Gladman DD (2011) SLEDAI-2K 10 days versus SLEDAI-2K 30 days in a longitudinal evaluation. Lupus 20: 67-70.

17. Ding JY, Ibañez D, Gladman DD, Urowitz MB (2015) Isolated hematuria and sterile pyuria may indicate systemic lupus erythematosus activity. J Rheumatol 42: 437-440.

18. Ishizaki J, Saito K, Nawata M, Mizuno Y, Tokunaga M, et al. (2015) Low complements and high titre of anti-Sm antibody as predictors of histopathologically proven silent lupus nephritis without abnormal urinalysis in patients with systemic lupus erythematosus. Rheumatology (Oxford) 54: 405-412.

19. Hahn BH, McMahon MA, Wilkinson A, Wallace WD, Daikh DI, et al. (2012) American College of Rheumatology guidelines for screening, treatment, and management of lupus nephritis. Arthritis Care Res (Hoboken) 64: 797-808.

20. Bertsias GK, Tektonidou M, Amoura Z, Aringer M, Bajema I, et al. (2012) Joint European League Against Rheumatism and European Renal Association-European Dialysis and Transplant Association (EULAR/ERA-EDTA) recommendations for the management of adult and paediatric lupus nephritis. Ann Rheum Dis 71: 1771-1782.

21. Houssiau FA (2012) Therapy of lupus nephritis: lessons learned from clinical research and daily care of patients. Arthritis Res Ther 14: 202.

22. Corapi KM, Dooley MA, Pendergraft WF 3rd (2015) Comparison and evaluation of lupus nephritis response criteria in lupus activity indices and clinical trials. Arthritis Res Ther 17: 110.
23. Myers BD (1990) Pathophysiology of proteinuria in immune glomerular injury. Am J Nephrol 10 1: 19-23

24. Onishi S, Adnan E, Ishizaki J, Miyazaki T, Tanaka Y, et al. (2015) Novel Autoantigens Associated with Lupus Nephritis. PLoS One 10: 0126564.

25. loannidis JP, Boki KA, Katsorida ME, Drosos AA, Skopouli FN, et al. (2000) Remission, relapse, and re-remission of proliferative lupus nephritis treated with cyclophosphamide. Kidney Int 57: 258-264.

26. Mavragani CP, Fragoulis GE, Somarakis G, Drosos A, Tzioufas AG, Moutsopoulos HM (2015). Clinical and laboratory predictors of distinct histopathogical features of lupus nephritis. Medicine (Baltimore) 94: 829.

27. So MW, Koo BS, Kim YG, Lee CK, Yoo B, et al. (2011) Predictive value of remission status after 6 months induction therapy in patients with proliferative lupus nephritis: a retrospective analysis. Clin Rheumatol 30:1399-1405.

28. Weening JJ, D'Agati VD, Schwartz MM, Seshan SV, Alpers CE, et al. (2014) The classification of glomerulonephritis in systemic lupus erythematosus revisited. J Am Soc Nephrol 15: 241-250.

29. Ronco P (2015) Moderator's view: Biomarkers in glomerular diseases--translated into patient care or lost in translation? Nephrol Dial Transplant 30: 899902

30. De Vriese AS, Fervenza FC2 (2015) Con: Biomarkers in glomerular diseases: putting the cart before the wheel? Nephrol Dial Transplant 30: 885-890.

31. Brunner HI, Bennett M, Abulaban K, Klein-Gitelman M, O’Neil K, et al. (2015) Development of a novel renal activity index of lupus nephritis in children \& young adults. Arthritis Care Res (Hoboken)

32. Rao V, Gordon C (2014) Advances in the assessment of lupus disease activity and damage. Curr Opin Rheumatol 26: 510-519.

33. Bombardier C, Gladman DD, Urowitz MB, Caron D, Chang CH (1992) Derivation of the SLEDAI. A disease activity index for lupus patients. The Committee on Prognosis Studies in SLE. Arthritis Rheum 35: 630-40.

34. Isenberg DA, Rahman A, Allen E, Farewell V, Akil M, et al. (2005) BILAG 2004. Development and initial validation of an updated version of the British Isles Lupus Assessment Group's disease activity index for patients with systemic lupus erythematosus. Rheumatology (Oxford) 44: 902-906.

35. ACCESS Trial Group (2014) Treatment of lupus nephritis with abatacept: the Abatacept and Cyclophosphamide Combination Efficacy and Safety Study. Arthritis Rheumatol 66: 3096-3104.

36. Appel GB, Contreras G, Dooley MA, Ginzler EM, Isenberg D, et al. (2009) Mycophenolate mofetil versus cyclophosphamide for induction treatment of lupus nephritis. J Am Soc Nephrol 20: 1103-1112.

37. Rovin BH, Furie R, Latinis K, Looney RJ, Fervenza FC, et al. (2012) Efficacy and safety of rituximab in patients with active proliferative lupus nephritis: the Lupus Nephritis Assessment with Rituximab study. Arthritis Rheum 64 $1215-1226$

38. Wofsy D, Hillson JL, Diamond B (2012) Abatacept for lupus nephritis: alternative definitions of complete response support conflicting conclusions. Arthritis Rheum 64: 3660-3665.

39. Touma Z, Gladman DD, Urowitz MB, Beyene J, Uleryk EM, et al. (2011) Mycophenolate mofetil for induction treatment of lupus nephritis: a systematic review and metaanalysis. J Rheumatol 38: 69-78.

40. Bae SC, Koh HK, Chang DK, Kim MH, Park JK, et al. (2001) Reliability and validity of systemic lupus activity measure-revised (SLAM-R) for measuring clinical disease activity in systemic lupus erythematosus. Lupus 10: 405-409.

41. Yee CS, Cresswell L, Farewell V, Rahman A, Teh LS, et al. (2010) Numerica scoring for the BILAG-2004 index. Rheumatology (Oxford) 49: 1665-1669.

42. Smolen JS (1987) Clinical and serological features. In: Smolen JS, Zelinsk CC (eds.). Systemic lupus erythematosus: clinical and experimental aspects. Berlin: Springer Verlag Pg no: 170-196.

43. Lee SY, Kim SI, Choi ME (2015) Therapeutic targets for treating fibrotic kid ney diseases. Transl Res 165: 512-530. 
44. Ferraccioli G, Romano G (2008) Renal interstitial cells, proteinuria and progression of lupus nephritis: new frontiers for old factors. Lupus 17: 533-540.

45. Remuzzi G, Bertani T (1990) Is glomerulosclerosis a consequence of altered glomerular permeability to macromolecules? Kidney Int 38: 384-394

46. Parikh SV, Nagaraja HN, Hebert L, Rovin BH (2014) Renal flare as a predictor of incident and progressive CKD in patients with lupus nephritis. Clin J Am Soc Nephrol 9: 279-284.

47. Touma Z, Urowitz MB, Medina-Rosas J, Su J, Gladman DD, et al. (2015) Do Patients with Lupus Nephritis Who Achieve Complete Proteinuria Recovery at 2 Years Have Better Long Term Outcomes Compared to Patients with Partial Proteinuria Recovery? Arthritis Rheumatol 67.

48. Lopez-Vargas PA, Tong A, Sureshkumar P, Johnson DW, Craig JC (2013) Prevention, detection and management of early chronic kidney disease: a systematic review of clinical practice guidelines. Nephrology (Carlton) 18: 592-604.

49. Renal Disease Subcommittee of the American College of Rheumatology Ad Hoc Committee on Systemic Lupus Erythematosus Response Criteria (2006) The American College of Rheumatology response criteria for proliferative and membranous renal disease in systemic lupus erythematosus clinical trials. Arthritis Rheum 54: 421-432.

50. Wofsy D, Hillson JL, Diamond B (2013) Comparison of alternative primary outcome measures for use in lupus nephritis clinical trials. Arthritis Rheum 65: 1586-1591.

51. Houssiau FA, D'Cruz D, Sangle S, Remy P, Vasconcelos C, et al. (2010) Azathioprine versus mycophenolate mofetil for long-term immunosuppression in lupus nephritis: results from the MAINTAIN Nephritis Trial. Ann Rheum Dis 69: 2083-2089.

52. Chan TM, Tse KC, Tang CS, Mok MY, Li FK (2005) Long-term study of mycophenolate mofetil as continuous induction and maintenance treatment for diffuse proliferative lupus nephritis. J Am Soc Nephrol 16: 1076-1084.

53. Dall'Era M, Cisternas MG, Smilek DE, Straub L, Houssiau FA, et al. (2015) Predictors of long-term renal outcome in lupus nephritis trials: lessons learned from the Euro-Lupus Nephritis cohort. Arthritis Rheumatol 67: 1305-1313.

54. Dall'Era M, Levesque V, Solomons N, Truman M, Wofsy D (2015) Identification of clinical and serological factors during induction treatment of lupus nephritis that are associated with renal outcome. Lupus Sci Med 2: 000089.

55. Fried L, Solomon C, Shlipak M, Seliger S, Stehman-Breen C, et al. (2004) Inflammatory and prothrombotic markers and the progression of renal disease in elderly individuals. J Am Soc Nephrol 15: 3184-3191.

56. Tonelli M, Sacks F, Pfeffer M, Jhangri GS, Curhan G, et al. (2005) Biomarkers of inflammation and progression of chronic kidney disease. Kidney Int 68 : $237-245$

57. Clark WF, Moist LM (1998) Management of chronic renal insufficiency in lupus nephritis: role of proteinuria, hypertension and dyslipidemia in the progression of renal disease. Lupus 7: 649-53.

58. Fiehn C, Hajjar Y, Mueller K, Waldherr R, Ho AD, et al. (2003) Improved clinical outcome of lupus nephritis during the past decade: importance of early diagnosis and treatment. Ann Rheum Dis 62: 435-439.

59. Reich HN, Gladman DD, Urowitz MB, Bargman JM, Hladunewich MA, et al (2011) Persistent proteinuria and dyslipidemia increase the risk of progressive chronic kidney disease in lupus erythematosus. Kidney Int 79: 914-920.

60. Shimbo Y, Suzuki S, Ishii H, Shibata Y, Tatami Y, et al. (2015) Association of Estimated Glomerular Filtration Rate and Proteinuria With Lipid-Rich Plaque in Coronary Artery Disease. Circ J 79: 2263-2270.

61. Matsushita K, Coresh J, Sang Y, Chalmers J, Fox C, et al. (2015) Estimated glomerular filtration rate and albuminuria for prediction of cardiovascular outcomes: a collaborative meta-analysis of individual participant data. Lance Diabetes Endocrinol 3: 514-525

62. Perkovic V, Verdon C, Ninomiya T, Barzi F, Cass A, et al. (2008) The relationship between proteinuria and coronary risk: a systematic review and meta-analysis. PLoS Med 5: 207.
63. Koenig KF, Ribi C, Radosavac M, Zulewski H, Trendelenburg M, et al. (2015) Prevalence of vascular disease in systemic lupus erythematosus compared with type-1 diabetes mellitus: a cross-sectional study of two cohorts. Lupus 24: 58-65.

64. Sutton EJ, Davidson JE, Bruce IN (2013) The Systemic Lupus International Collaborating Clinics (SLICC) damage index: a systematic literature review. Semin Arthritis Rheum 43: 352-361.

65. Frieri M, Stampfl H (2016) Systemic lupus erythematosus and atherosclerosis: Review of the literature. Autoimmun Rev 15: 16-21.

66. Culleton BF, Larson MG, Parfrey PS, Kannel WB, Levy D (2000) Proteinuria as a risk factor for cardiovascular disease and mortality in older people: a prospective study. Am J Med 109: 1-8.

67. Haider YS, Roberts WC (1981) Coronary arterial disease in systemic lupus erythematosus; quantification of degrees of narrowing in 22 necropsy patients (21 women) aged 16 to 37 years. Am J Med 70: 775-781.

68. Font J, Ramos-Casals M, Cervera R, García-Carrasco M, Torras A, et al. (2001) Cardiovascular risk factors and the long-term outcome of lupus nephritis. QJM 94: 19-26.

69. Fernandez-Nebro A, Rua-Figueroa I, Lopez-Longo FJ, Galindo-Izquierdo M, Calvo-Alen J, et al. (2015) Cardiovascular Events in Systemic Lupus Erythematosus: A Nationwide Study in Spain From the RELESSER Registry. Medicine (Baltimore) 94: 1183

70. Falaschi F, Ravelli A, Martignoni A, Migliavacca D, Sartori M, et al. (2000) Nephrotic-range proteinuria, the major risk factor for early atherosclerosis in juvenile-onset systemic lupus erythematosus. Arthritis Rheum 43: 1405-1409.

71. Kammoun K, Jarraya F, Bouhamed L, Kharrat M, Makni S, et al. (2011) Poor prognostic factors of lupus nephritis. Saudi J Kidney Dis Transpl 22: 727-732.

72. Chen YE, Korbet SM, Katz RS, Schwartz MM, Lewis EJ, et al. (2008) Value of a complete or partial remission in severe lupus nephritis. Clin J Am Soc Nephrol 3: 46-53.

73. Bargman JM, Avila-Casado C (2014) Resolution of proteinuria in lupus nephritis: hurry up and wait. J Rheumatol 41: 622-625.

74. Dye-Torrington D, Urowitz, Murray B, Ibanez, Dominique I, et al. (2011) Late Versus Early Development of Lupus Nephritis. Arthritis Rheum 63: 2284.

75. Antunes VV, Veronese FJ, Morales JV (2008) Diagnostic accuracy of the protein/creatinine ratio in urine samples to estimate $24-h$ proteinuria in patients with primary glomerulopathies: a longitudinal study. Nephrol Dial Transplant 23: 2242-2246.

76. Medina-Rosas J, Gladman DD, Su J, Sabapathy A, Urowitz MB, et al. (2015) Utility of untimed single urine protein/creatinine ratio as a substitute for $24-h$ proteinuria for assessment of proteinuria in systemic lupus erythematosus. Arthritis Res Ther 17: 296.

77. Chotayaporn T, Kasitanon N, Sukitawut W, Louthrenoo W (2011) Comparison of proteinuria determination by urine dipstick, spot urine protein creatinine index, and urine protein 24 hours in lupus patients. J Clin Rheumato 17: $124-129$

78. Siedner MJ, Gelber AC, Rovin BH, McKinley AM, Christopher-Stine L, et al. (2008) Diagnostic accuracy study of urine dipstick in relation to 24-hour measurement as a screening tool for proteinuria in lupus nephritis. J Rheumatol 35: 84-90.

79. Siedner MJ, Christopher-Stine L, Astor BC, Gelber AC, Fine DM (2007) Screening for proteinuria in patients with lupus: a survey of practice preferences among American rheumatologists. J Rheumatol 34: 973-977.

80. Medina-Rosas J, Gladman DD, Su J, Sabapathy A, Urowitz MB, et al. Utility of untimed single urine protein/creatinine ratio as a substitute for the 24 hour proteinuria for the assessment of proteinuria in systemic lupus erythematosus. Arthritis Res Ther 17: 296.

81. Medina-Rosas J, Yap KS, Anderson M, Su J, Touma Z, et al. (2015) Diagnostic and screening accuracy of spot urinary Protein-Creatinine ratio compared to protein content in a 24 hour-urine collection in systemic lupus Erythematosus: Systematic review and meta-analysis Arthritis Rheumatol 67: 2908.

82. Chitalia VC, Kothari J, Wells EJ, Livesey JH, Robson RA, et al. (2001) Cost-benefit analysis and prediction of 24-hour proteinuria from the spot urine protein-creatinine ratio. Clin Nephrol 55: 436-447. 
83. Choi IA, Park JK, Lee EY, Song YW, Lee EB (2013) Random spot urine protein to creatinine ratio is a reliable measure of proteinuria in lupus nephritis in Koreans. Clin Exp Rheumatol 31: 584-588.

84. Birmingham DJ, Rovin BH, Shidham G, Nagaraja HN, Zou X, et al. (2007) Spot urine protein/creatinine ratios are unreliable estimates of $24 \mathrm{~h}$ proteinuria in most systemic lupus erythematosus nephritis flares. Kidney Int 72 : 865-870.
85. Birmingham DJ, Shidham G, Perna A, Fine DM, Bissell M, et al. (2014) Spot $\mathrm{PC}$ ratio estimates of 24 -hour proteinuria are more unreliable in lupus nephritis than in other forms of chronic glomerular disease. Ann Rheum Dis 73: $475-476$.

86. Leung YY, Szeto CC, Tam LS, Lam CW, Li EK, et al. (2007) Urine protein-to-creatinine ratio in an untimed urine collection is a reliable measure of proteinuria in lupus nephritis. Rheumatology (Oxford) 46: 649-52. 